\title{
Estilhaços da memória no pântano da história: Noite dentro da noite, de J. R. Terron
}

\author{
Shards of Memory in the Marsh of History: \\ Noite dentro da noite, by J. R. Terron \\ Proyectiles de la memoria en el pantano de la historia: \\ Noite dentro da noite, de J.R. Terron \\ Rita Olivieri-Godet
}

\section{Resumo}

A memória da infância, num país sob regime militar, alimenta a narrativa de Noite dentro da noite. Embora ancorada na ditadura de 1964, ela evoca, igualmente, o período que lhe antecede e que lhe é posterior, captando a barbárie de uma "era dos extremos", através do filtro de uma visão apocalíptica e profética. Afastando-se de uma representação realista, privilegia a transfiguração expressionista dos sucessivos genocídios em cenários onde evoluem personagens em situações extremas. $\mathrm{O}$ artigo destacará a perspectiva niilista do romance que representa a existência agônica desses seres através das múltiplas imagens alegóricas da paisagem labiríntica e tenebrosa da selva do Pantanal.

Palavras-chave: Noite dentro da noite, ditadura militar, violência, pós-memória, herança traumática.

\begin{abstract}
The memory of childhood, in a country under military rule, feeds the narrative of Noite dentro da noite [Night Within Night]. Although anchored in the dictatorship of 1964, the novel also evokes the periods before and after it, capturing the barbarism of an "age of extremes" through the filter of an apocalyptic and prophetic vision. Moving away from a realistic representation, it privileges the expressionist transfiguration of successive genocides, in scenarios where characters evolve in extreme situations. This article will highlight the nihilistic perspective of the novel which represents the agonizing existence of these beings through the multiple allegorical images of the labyrinthine and gloomy landscape of the Pantanal jungle.
\end{abstract}

Keywords: Noite dentro da noite, military dictatorship, violence, post-memory, traumatic inheritance.

\section{Resumen}

La memoria de la infancia en un país bajo régimen militar alimenta la narrativa de Noche dentro de la noche. Aunque situada en la dictadura de 1964, evoca, igualmente, el periodo anterior y posterior, captando la barbarie de una "era de extremos" a través del filtro de una visión apocalíptica y profética. Se aleja de la representación realista y opta por la transfiguración expresionista de los sucesivos genocidios, en cuyos escenarios evolucionan los personajes en situaciones extremas. El artículo destacará la perspectiva nihilista de la novela que representa la existencia agónica de estos seres, mediante las múltiples imágenes alegóricas del paisaje laberíntico y tenebroso de la selva del Pantanal brasileño.

Palabras-clave: Noche dentro de la noche, dictadura militar, violencia, posmemoria, herencia traumática.

Lasciate ogne speranza, voi ch'intrate.

Dante Alighieri, "Inferno", La divina commedia

Devant ces voyageurs, pour lesquels est ouvert

L'empire familier des ténèbres futures.

Charles Baudelaire, Les fleurs du mal

\footnotetext{
*Université Rennes 2, Rennse, Paris, França. Dorcid.org/0000-0003-0635-5673. E-mail: ritagodet20@ gmail.com
} 
Noite dentro da noite (2017a), do escritor matogrossense Joca Reiners Terron (Cuiabá, 1968), submerge o leitor num universo labiríntico, espectral e violento, levando-o a compartilhar experiências extremas projetadas no contexto de uma sociedade em crise. $\mathrm{O}$ texto elabora uma visão crepuscular da humanidade: as trevas do passado transbordam e invadem o presente, impossibilitando qualquer esperança no futuro. A leitura do romance se realiza como uma experiência mimética dos deslocamentos físicos, mentais e agônicos dos personagens, interpelando, ao mesmo tempo, a memória de livros do leitor: "insinuou-se em sua memória a imagem esmaecida de uma longa viagem sonolenta por estradas escuras, uma viagem que parecia um pesadelo do qual nunca acordaria, a travessia noturna de uma região pantanosa" (Terron, 2017a, p 79-80). Floresta de signos que ressignificam um imaginário dantesco, fundamentado em visões que engendram a extraordinária violência do universo ficcional, povoado de monstros, ditadores, assassinos, torturadores, personagens diabólicos e suas vítimas que transitam por paisagens ameaçadoras e desoladoras. As imagens hiperbólicas exploradas pelo romance configuram um universo de caráter desumano que a representação espacial reforça ao explorar aspectos inquietantes pelo viés de uma figuração fantástica e fantasmagórica da natureza. $O$ espaço referencial central é o da fronteira entre o Chaco paraguaio e o do pantanal matogrossense, região marcada pela guerra, pelas ditaduras militares e pelo genocídio de povos indígenas. Penetrar nessa selva escura não é uma tarefa fácil: como todo grande romance, a "saga pantanosa [...] feita de lama movediça" (Terron, 2017a, p. 437), habitada por fantasmas, é plural e inesgotável. Sua epígrafe lembra-nos que os fantasmas são donos de tudo. ${ }^{1}$ Ela inspira o fio condutor temático e a densa complexidade formal de uma obra dedicada à rememoração de acontecimentos traumáticos e suas ressonâncias no presente, apoiada numa modelização narrativa orientada pelo princípio da virtualidade do real. Entre os múltiplos aspectos explorados pelo romance, limitar-me-ei a comentar as relações entre memória, história e ficção, tomando, como eixo central da reflexão, a apreensão e a recriação, pelo universo ficcional, da ditadura militar no Brasil.

\section{Memória dos traumas: ressonâncias e conexões}

Na obra intitulada A persistência da memória, Zilá Bernd revisita as teorias sobre a memória cultural e a memória geracional, dedicando-se à leitura de alguns "romances da anterioridade" que reelaboram os vestígios memoriais para ressignificar o presente, marcados por um duplo movimento: o da aceitação da ancestralidade ou o da negação da herança considerada maldita, atravessada por memórias traumáticas. A autora chama a atenção para as relações entre memória e contemporaneidade, ao lembrar que, segundo Andreas Huyssen, "O tempo do ato de memória é o presente e não o passado, embora toda memória dependa de alguma experiência que ocorreu no passado" (Bernd, 2018, p. 22). A persistência do passado no presente ou, no dizer de Beatriz Sarlo, "o passado [que] se faz presente" (Sarlo, 2007, p. 10) é uma das tendências temáticas das narrativas contemporâneas que se dedicam à rememoração de acontecimentos traumáticos e às suas repercussões na atualidade, conscientes das intricadas e conflituosas relações entre memória e história. Andreas Huyssen alude ao caráter a um só tempo evanescente e iluminador da memória, por meio de uma imagem metafórica que coincide com a perspectiva abraçada por Joca Reiners Terron em Noite dentro da noite: "Ocaso (twilight) é o momento do dia que antecede a noite do esquecimento; um entre-lugar em que a última luz do dia ainda pode efetuar maravilhas. É o tempo privilegiado da memória" (Huyssen, 2000, p. 19-21).

A narrativa ficcional de Terron afina-se com a tendência à "emergência da memória" que Huyssen constata na produção contemporânea. Ancorada na história de uma família de

\footnotetext{
${ }^{1}$ A epígrafe corresponde à tradução de um poema do poeta americano contemporâneo Graham Foust (1970): "E os fantasmas / eles são donos de tudo" ("And the ghosts / they own everything").
} 
imigrantes alemães, ela interconecta elementos da vivência do autor com acontecimentos trágicos da memória cultural, explorando os limites da representação de experiências extremas. Trata-se de uma memória que agrega lembranças pessoais ou familiares às reminiscências de um mundo não vivenciado, uma experiência compartilhada de forma indireta por mediações diversas, processo que Marianne Hirsch nomeou de pós-memória: "A noção de 'pós-memória' designa a relação que a 'geração seguinte' mantém com o traumatismo pessoal, coletivo e cultural que aqueles que a precederam sofreram, com experiências das quais ela só se lembra por intermédio de histórias, de imagens e de comportamentos no seio dos quais ela cresceu" (Hirsch, 2013, p. 6, tradução nossa). A autora refere-se a uma memória herdada de acontecimentos traumáticos, construída indiretamente por discursos fragmentados sobre um passado cujas consequências se prolongam no presente.

Em Noite dentro da noite, a problematização da memória do passado traumático se dá entre ruínas e visões, num processo complexo de construção de sentidos instáveis prenunciados no próprio título do livro: "noite dentro da noite, pyhareryepypepyhare, o instante mais denso de escuridão que antecede o alvorecer incerto" (Terron, 2017a, p. 144). A estranha e impronunciável palavra indígena pyhareryepypepyhare remete à complexidade da concepção do tempo pelos Mbyá-Guarani. O romance submete-a a um trabalho polissêmico, guardando uma relação de sentido que permite conectar várias camadas da memória cultural. Consciente da impossibilidade de abarcar o Real, apoia-se numa rede simbólica para configurá-lo, perpassada por figuras que projetam o movimento intervalar e efêmero da memória. Situa-se, dessa maneira, num limiar metafórico-escritural que mimetiza as zonas de fronteira e o próprio ato imaginativo do escritor.

Em entrevista, Terron (2017b) admite que algumas experiências de sua trajetória de vida inspiram a construção do protagonista desmemoriado e mudo do romance, em consequência de um acidente que sofreu na infância. Apesar do subtítulo "Uma autobiografia" e da inclusão de alguns elementos biográficos, não existe, no entanto, por parte do autor, nenhuma intenção de realizá-la, muito menos nos moldes de um relato testemunhal: "Todo livro é autobiográfico, mas são biografias editadas, distorcidas para se encaixarem na visão que temos de nós mesmos" (Terron, 2017b, s.p.). A afirmação revela certo ponto de vista sobre um fazer literário que problematiza a reconstrução narrativa das experiências vividas, dos relatos de rememoração das vítimas e de outras formas de transmissão das imagens coletivas da herança traumática. $\mathrm{Na}$ mesma entrevista, Terron confessa sua obsessão por determinados temas: "Escrever a respeito da infância passada num país sob regime militar, por exemplo, é algo que diz respeito somente à minha geração" (Terron, 2017b, s.p.). Como dar conta da rememoração da experiência de um menino durante a ditadura? Como evocar esse período e a memória herdada de outros acontecimentos trágicos que o precederam? Segundo Marianne Hirsch, a conexão com o passado exige "investimento imaginário, projeção e criação" (Hirsch, 2013, p. 6, tradução nossa). Na visão de Terron, "a imaginação e a mentira servem para que a ficção se aproxime mais da verdade" (Terron, 2017c, s.p.). A imaginação sustenta a urdidura da trama cujos dispositivos de textualização problematizam as relações entre memória e esquecimento, questionando a identidade do sujeito da enunciação, através de procedimentos que confundem a voz do autor com as categorias textuais do narrador e do personagem.

A produção literária sobre a ditadura militar inicia-se desde os primórdios do golpe e prolonga-se até os dias atuais. Como bem assinala Andrea Hossne, escritores da geração de Terron tiveram, como ele, uma formação contaminada pelos vestígios da ditadura, presentes nas estruturas de educação institucional, nas relações humanas e interações sociais quotidianas (Hossne, 2016, p. 43). Eles inauguram outras modalidades de representação desse período dramático da história do Brasil para além da perspectiva do realismo crítico, predominante na produção romanesca dos "anos de chumbo", embora, segundo Tânia Pellegrini, os caminhos da refração ao realismo tradicional, como a literatura fantástica em Incidente em Antares, de Erico Veríssimo (1971/1977), ou o recurso à narrativa fragmentada em Zero, de Ignácio de Loyola Brandão (1971/1982), tenham recorrido a outras formas de representar a mesma realidade, "quase escapando da intenção mimética" (Pellegrini, 2018, p. 208). 
A diversidade de perspectivas estéticas também é observada no estudo em que Regina Dalcastagnè se dedica à representação do regime de 64 no romance (Dalcastagnè, 1996), no qual a autora examina nove romances publicados na década de 1970 e 1980, precisando as relações entre as questões ideológicas e o tecido discursivo de cada um deles. A constatação de um tratamento estético diverso, no que diz respeito à representação desse momento político no Brasil, aparece igualmente na obra de Eurídice Figueiredo, que propõe uma sistematização dessa produção, identificando três períodos: i) 1964-1979, marcado pela tônica "ora prospectiva e utópica, ora distópica diante do fracasso dos projetos revolucionários" (Figueiredo, 2017, p. 47); ii) 1979-2000, no qual se sobressaem os "relatos autobiográficos de ex-presos políticos exilados" (Figueiredo, 2017, p. 48); e iii) 2000-2016, "retrospectivo, aborda o passado de pessoas reais ou fictícias, utilizando a forma do romance para transmutar o vivido através de um trato mais literário" (Figueiredo, 2017, p. 49). Publicado em 2017, a extraordinária densidade e complexidade de Noite dentro da noite corrobora essa tendência do último período identificado pela autora no tratamento da representação da ditadura militar.

O romance está alicerçado em resíduos de uma memória simultaneamente íntima e coletiva que se fazem presentes no processo de transferência transgeracional do trauma (Hirsch, 2013). Se a memória da infância num país sob regime militar fecunda a narrativa de Noite dentro da noite, o que interessa é observar como essa memória é reelaborada pela imaginação criadora de um autor cuja linguagem, profundamente dialógica, é atravessada por diferentes tipos de discurso por meio dos quais se textualizam as inúmeras referências às tradições literárias diversas, à produção cinematográfica e às imagens disseminadas pelos meios de comunicação audiovisuais. Opta, então, por um regime discursivo polifônico que vai modulando significados por intermédio de imagens multifacetadas, instaurando diversos planos no seio de uma narrativa fragmentada. O processo de escritura, inspirado na estrutura mnemônica, inaugura novos aspectos temáticos e formais, levando o leitor a fazer uma experiência impactante e original: "Os mecanismos da memória são tortuosos, parecidos com os dos sonhos, ou dos pesadelos" (Terron, 2017a, p. 151). Desprezando o princípio da verossimilhança, Terron privilegia a transfiguração expressionista dos sucessivos genocídios evocados pela trama romanesca, construindo cenários fantasmagóricos atravessados por uma atmosfera de suspense e horror, nos quais evoluem personagens em situações extremas.

Sendo assim, a narrativa fundamentada no trabalho de reconstrução do passado recorre às dimensões individual, genealógica, histórica e coletiva da memória que surgem imbricadas e ressignificadas pelo presente. Embora ancorada na ditadura de 1964, abrange, igualmente, o período que the antecede e o que lhe é posterior, captando a barbárie de uma "era dos extremos", epíteto que o historiador Eric Hobsbawm (2003) atribui ao século XX. Na perspectiva da ficção, a "era dos extremos" é ampliada, tendendo a uma figuração atemporal da barbárie, projetada como herança do passado que compõe o presente e semeia o futuro.

Pelo filtro de uma visão apocalíptica e profética, o romance incorpora diversos estratos históricos que se superpõem, rememorando, de maneira fragmentada e descontínua, as experiências trágicas das guerras do Paraguai (1864-1870) e da Segunda Guerra Mundial (19391945); da "Era Vargas" e do período da repressão da ditadura (1930-1945); da ditadura militar e da Guerrilha do Araguaia (1964-1985), eixo em torno do qual todos os outros se articulam, reverberando o terror. Contrapondo-se ao apagamento da memória, vasculha fatos que marcaram e conformaram o território do Chaco paraguaio e do Pantanal, revisitando a história da fundação, por imigrantes alemães, da colônia ariana Nueva Germania, no Chaco paraguaio (1887), idealizada por Bernhard Förster e Elizabeth Förster-Nietzsche, irmã do célebre filósofo alemão. Refere-se ao processo de espoliação territorial e à violência contra os povos indígenas, incorporados à narrativa como figuras fantasmagóricas da "natureza selvagem" do Chaco paraguaio e do sul do Mato Grosso, espectros que perambulam nos territórios e fronteiras dessas nações construídas sobre seus cadáveres, na contramão da narrativa canônica oficial que relega a história dos atores sociais indígenas ao esquecimento.

Dedicando-se a uma "memória do esquecimento" (Agamben, 2008), a fatura romanesca mimetiza a instabilidade das falhas da memória, cujo exemplo mais significativo manifesta-se 
na construção do protagonista, um menino desmemoriado em busca da reconstituição do seu passado. A escolha, pelo autor, de modalidades narrativas, como a descontinuidade, a fragmentação, o estilhaçamento do sentido e a metatextualidade, denota a consciência do caráter enigmático do real e, por conseguinte, a desconfiança em relação à ideia da possibilidade de apreender a história na sua totalidade: a forma lacunar do romance afasta-o, radicalmente, da restituição linear e sistemática da história, optando por uma reconstrução apoiada nas errâncias da memória, tendência característica de vários textos da produção contemporânea, como bem observa Dion (2019b, p. 156). A escrita do romance se realiza como um ato memorialístico palimpsesto interconectando, de maneira imprecisa, imagens fantasmas das ruínas da história da humanidade.

No seio dos acontecimentos caóticos e traumáticos, o romance projeta a existência agônica dos personagens em múltiplos deslocamentos que terminam sempre na selva do Pantanal matogrossense e do Chaco paraguaio, região de fronteira entre Brasil e Paraguai, estabelecendo conexões com espaços de extermínio nazistas na Alemanha da Segunda Guerra. Seus destinos estão intimamente ligados à história trágica desse território pantanoso, cujas propriedades físicas dos elementos naturais e dos organismos vivos que o compõem expõem a decomposição e a putrefação da vegetação, favorecendo a composição alegórica da selva pantanosa como teatro da morte: espaço labiríntico, lúgubre, povoado de monstros e fantasmas. Assim, o regime discursivo do romance imprime um sentido alegórico à materialidade da paisagem, tecendo correspondências que fazem emergir imagens espectrais que a transfiguram num cenário de horror: a paisagem alegórica é narrativamente orientada, fomentando o imaginário de um inferno espectral. Christophe Imbert e Philippe Maupeu, (2012, p. 33) destacam que a tensão figurativa se instaura através da dialética da intenção alegórica e da técnica do realismo, que corresponde a uma das tendências que atravessam a produção literária pós-moderna recente, herdeira da alegoria baudelairiana, das vanguardas modernas, do realismo mágico, para tentar escapar às armadilhas do realismo como convenção.

A figura mais emblemática do funcionamento alegórico do regime discursivo do autor é a pyhareryepypepyhare, palavra derivada da língua mbyá-guarani. Sua tradução em português mantém a ambiguidade dos múltiplos significados associados a um mundo insólito, delirante, violento e obscuro, sustentando a atmosfera inquietante da narrativa. Assim, a opacidade do significante é reforçada pelas sucessivas traduções do seu significado: flor-vampiro, flor selvagem, planta carnívora, praga vegetal, líquen, bactéria, ser sobrenatural e vários outros sentidos que modelam seu caráter polissêmico e sua condição transitória e indefinida:

noite dentro da noite, pyhareryepypepyhare, o instante mais denso de escuridão que antecede o alvorecer incerto, $\mathrm{o}$ instante mais negro de toda a existência, pois não se sabe se haverá o seguinte. O limbo (Terron, 2017a, p. 144).

Os índios a chamavam [a enfermidade] de pyhareryepypepyhare, disse Hugo em sua chegada, mas eu a chamo de morte de tudo que está vivo (Terron, 2017a, p. 379).

pyhareryepypepyhare é feita de visgo, de breu, de limo, de musgo, de líquen, é o céu um segundo antes do trovão, é ar espesso, água de poça que restou da chuva, fuligem se dissipando na noite, é cinza voando na escuridão (Terron, 2017a, p. 64-65).

Enquanto flor-vampiro, a pyhareryepypepyhare está vinculada às catástrofes evocadas no romance, que se alastram como doenças contagiosas. Ela permeia os diversos planos narrativos, acolhendo uma carga alegórica que evoca as múltiplas manifestações do mal no passado e no horizonte da humanidade:

A pyhareryepypepyhare havia sido levada por Felinto Muller ao Centro de Eutanásia como objeto de pesquisa de cientistas liderados pelo dr. Irmfried Eberl, depois incorporada ao grupo de meninos judeus sob os cuidados do então jovem bioquímico, deficientes que eram usados como cobaias em pesquisas com o fenobarbital. Então pyhareryepypepyhare não passava de um microrganismo desconhecido, uma bactéria que prometia ser a origem 
de novas armas químicas, que se desenvolveu e se tornou um líquen, a flor-vampiro (Terron, 2017a, p. 209).

o inevitável irrompimento de pyhareryepypepyhare entre os homens, o índio anunciava o fim do mundo (Terron, 2017a, p. 239).

A história que a narrativa elabora sobre a pyhareryepypepyhare favorece as conexões entre as diferentes catástrofes. Teria sua origem na zona pantanosa (Terron, 2017a, p. 209), tendo sido levada para o Centro de Eutanásia de Bernburg para ser utilizada em experiências com meninos judeus por Felinto Muller, chefe da polícia de Getúlio Vargas, e por El Cazador Blanco, personagem ficcional caracterizado como o principal torturador sob as ordens de Muller. Voltou ao Pantanal no submarino U-564, no qual se encontrava o alemão desfigurado Kurt Meyer, sobrevivente do ataque que afundou o submarino (Terron, 2017a, p. 211). A pyhareryepypepyhare interliga, através de imagens analógicas, as múltiplas catástrofes do passado ressuscitadas pelos desvios narrativos do texto, superpondo as camadas da memória cultural.

\section{No pântano da história}

O enredo do romance se constrói em torno da crise identitária de um menino desmemoriado e mudo, cuja infância e adolescência evoluem no contexto da ditadura militar brasileira. Reapropria-se de fatos históricos e de textos literários que exploraram a temática da luta armada e da repressão, encenando os "anos de chumbo" da ditadura, tomando como ponto de partida um acontecimento histórico: o sequestro do embaixador alemão Ehrenfried von Holleben em 1970. O romance de Terron dará ao tema da luta armada no Brasil um tratamento diferenciado dos textos precedentes que revisitaram essa história. Não se trata mais, para o autor, de elaborar uma representação realista expondo as batalhas ideológicas travadas na época ou de testemunhar a experiência da guerrilha, ${ }^{2}$ até porque não a viveu. Opta por desviarse dos dados factuais, investindo na ficcionalidade, convocando novos sentidos a partir da fatura complexa, intricada e radicalmente inovadora da narrativa. A esse núcleo temático encontram-se conectados vários outros associados aos acontecimentos traumáticos referidos na trama romanesca, mediante a interação de personagens, como os da saga familiar dos Reiners, ou as formas espectrais ameaçadoras, a exemplo da pyhareryepypepyhare e dos desdobramentos da figura do perseguidor/torturador, configurações diversas do legado da violência e da representação simbólica do mal.

A atmosfera estranha e aterrorizante do romance aposta no pathos inquietante, transformando uma simples brincadeira de esconde-esconde num acontecimento trágico, $\mathrm{o}$ acidente referido como "O Ano do Grande Branco", quando o menino bateu a cabeça e perdeu a memória. Cabe ao narrador, identificado com o nome do tradutor alemão de obras literárias brasileiras, Curt Meyer-Clason, contar ao menino a sua própria história, narrando-a em segunda pessoa, depois de ouvi-la na fita cassete gravada pela rata, mãe adotiva da criança: "Esta história é sobre você, mas vai contá-la como se fosse sobre outro" (Terron, 2017a, p. 12). A mediação da voz do narrador pela gravação reforça a estrutura complexa do romance, que problematiza a autoridade narrativa, multiplicando e imbricando vozes, planos narrativos e pontos de vista, e tecendo, em forma de mosaico, os fios da história, da qual Curt Meyer-Clason também participa enquanto personagem. O texto romanesco evoca fatos da biografia do célebre tradutor de Guimarães Rosa, referindo-se ao período de sua prisão em Ilha Grande, sob a acusação de espião do Terceiro Reich, durante a ditadura de Vargas. A instabilidade das identidades narrativas amalgama os planos subjetivo e coletivo da experiência histórica.

\footnotetext{
${ }^{2}$ A luta armada e os sequestros de embaixadores no Brasil foram tema de várias narrativas ficcionais, a exemplo de Reflexos do baile, de Antonio Callado (1977), e de Em câmara lenta, de Renato Tapajós (1977), ou de relatos testemunhais, como o célebre $O$ que é isso companheiro, de Fernando Gabeira (1979), e Os carbonários: memórias da guerrilha perdida, de Alfredo Sirkis (1980/2014), que rememora sua participação na história do sequestro do embaixador alemão Ehrenfried von Holleben, em 11 de junho de 1970. O sequestro permitiu a liberação de quarenta presos políticos em troca da vida do embaixador. No romance de Terron (2017a), o embaixador morre e seu filho é sequestrado por um dos guerrilheiros.
} 
O itinerário de vida do menino desmemoriado é marcado por traumas sucessivos cujas consequências perduram na adolescência e no início da idade adulta. $\mathrm{Na}$ trama romanesca, o menino é filho de um embaixador alemão morto durante uma tentativa de sequestro. A criança é levada, aos 4 anos de idade, pelo guerrilheiro Karl Reiners, para a casa da rata, denominação que o menino sequestrado atribui à sua mãe adotiva, a irmã de Karl, casada com um bancário que sucumbirá às pressões do contexto e terminará se suicidando. O casal já tem um filho, e uma relação de amizade fraterna se estabelece entre as duas crianças. As consequências do contexto violento da ditadura na vida de pessoas sem envolvimento com a luta armada também é matéria do romance, através da encenação do destino trágico do casal de pais adotivos.

No inverno de 1975, em Medianeira, no Paraná, referido como "o Ano do Grande Branco",3 os acidentes se sucedem na vida do menino: na volta do hospital, após ter perdido a memória durante a brincadeira de esconde-esconde, ele mata seu irmão adotivo ao brincar com o revólver "daquele que se dizia seu pai". A família, que já vinha recebendo ameaças de guerrilheiros que queriam recuperar o menino de volta, decide fugir, terminando por se estabelecer na pequena cidade de Curva de Rio Sujo, ${ }^{4}$ no Mato Grosso do Sul.

O acúmulo de imprevistos trágicos justifica a construção do vazio ontológico do personagem do menino. Solitário, mergulha num universo delirante no qual a imaginação preenche as lacunas da memória. Para fugir à hostilidade e à violência do mundo exterior, refugia-se na leitura: "Os livros lhe faziam bem, mesmo que não entendesse o que diziam" (Terron, 2017a, p. 45). Manifesta um interesse particular pela história da Guerra do Paraguai. Esse detalhe da intriga permite a superposição e imbricação de planos entre o presente da narrativa romanesca e a evocação da Guerra do Paraguai, através de obras dos primeiros historiadores e testemunhas da guerra. A referência à A retirada da Laguna (1867), de Alfredo EscragnolleTaunay (Terron, 2017a, p. 46), reforça a construção do Pantanal como teatro da morte, permitindo ao romance relembrar a batalha de Nandipá, ocorrida em 7 de maio de 1867. Tratase de uma das dramáticas derrotas do exército brasileiro, obrigado a bater em retirada para o Mato Grosso: "As ruínas carcomidas do obelisco de ponta quebrada dedicado à memória da batalha demonstrava o que aquele terreno era na verdade: nada além de cemitério antigo, habitado por lacraias e lagartixas" (Terron, 2017a, p. 152-153).

A escrita romanesca, imitando a arqueologia histórica, escava a memória da Guerra do Paraguai, assim como em outros momentos recupera o passado relacionado à Guerrilha do Araguaia ou à despossessão territorial e o consequente massacre dos povos indígenas. A memória dos livros revisitada - ilustrada aqui pela reapropriação dos textos sobre a Guerra do Paraguai que ajudaram a forjar um imaginário sobre o território - revela um fazer literário que se elabora como um ato memorialístico palimpsesto através do qual se busca reescrever um novo texto.

A outra obra destacada, apresentada como o livro predileto do menino, corresponde ao clássico relato do oficial paraguaio Juan Crisóstomo Centurión, Memórias ou reminiscências históricas sobre a Guerra do Paraguai (1894). Essas narrativas rememoram episódios da Guerra do Paraguai, assemelhando-se a romances de aventura. Paralelamente aos ambientes aterrorizantes do território do Pantanal que elas descrevem, a ficção de Terron inclui alguns personagens históricos, como os lanceiros kadiwéus que lutaram sob bandeira brasileira (Terron, 2017a, p. 46), e dá forma a personagens fantasmagóricos, a exemplo do guerreiro El Diablo, kadiwéu perseguido pelos paraguaios, com o qual o menino se identifica. Memória, história e ficção entrelaçam-se na criação romanesca do autor, atravessada por múltiplos discursos e linguagens artísticas e midiáticas, aderindo a uma estética que hipostasia os elementos negativos.

\footnotetext{
${ }^{3}$ A referência à tempestade de neve que caiu em Medianeira, no Paraná, em 1975, servirá de elemento impulsionador de uma série de imagens construídas em torno da cor branca que metaforizam as falhas da memória. Camila Von Holdefer (2017) assinala a sensação de irrealidade que emana dessas imagens, não somente em relação ao protagonista. O branco contamina toda a narrativa e se faz presente em imagens espectrais ou na evocação das esculturas de gelo da rata que reforçam o caráter imagético do texto, desvelando a luminosidade da linguagem que lhe é inerente.

${ }^{4}$ Título de outro livro de Joca Reiners Terron, Curva do rio sujo (2003), que também explora a relação com o tempo e a questão da memória. Sobre essa obra, ver Hossne (2016).
} 
Assim, a imaginação do menino é um poço de desassossego diante da ausência de vestígios memoriais familiares que o impossibilita de estabelecer o fio da ancestralidade. O entorno social violento da ditadura militar contribui para aguçar o caos interior. O contexto da ditadura é representado por meio da estrutura autoritária do estabelecimento escolar, metonímia da ordem social antidemocrática e arbitrária que promove a violência. A representação hiperbólica da violência se dá através de descrições minuciosas da imagem do corpo do menino sendo torturado por um grupo de colegas de sua classe, filhos de militares que "traziam a lógica da caserna para a sala de aula" (Terron, 2017a, p. 57). A aceitação passiva, por parte dele e da família, da recorrência desses atos de extrema violência, revela a impotência do indivíduo diante do poder totalitário que se fortalece com a indiferença e o silêncio cúmplice da sociedade: "Nas ruas sem pavimentação de Curva de Rio Sujo ninguém parecia preocupado com a ditadura escolar, disse Curt Meyer-Clason, com a opressão que o torturava na sexta série. Todos viviam suas vidas sem se darem conta do horror" (Terron, 2017a, p. 55).

A ideia da violência como legado de contextos históricos extremos atravessa a narrativa, moldando padrões de comportamento que se reproduzem por várias gerações, no interior dos núcleos familiares e sociais: "É assim que mí papá hace con los comunas, disse Hassan Sader Gamorra, y ellos siempre hablan todo" (Terron, 2017a, p. 61). Herdeiros da colonização que escravizou os negros e massacrou as populações nativas, as elites da nação perpetuam o legado racista e autoritário, como fica evidente na tipificação dos adolescentes que habitualmente torturam o menino:

Nasceram para herdar o comando que pertencia a seus pais e antes disso a seus avós, era gente que estava ali havia muito tempo e aquilo que faziam, o modo como se comportavam, a natureza exata de seus movimentos, mesmo na algazarra, era um indício de sua inferioridade diante deles, de sua pequenez insofismável (Terron, 2017a, p. 59).

Nas descrições das cenas de tortura, o romance apela para o realismo bruto, espelhando, de maneira hipertrófica, o gozo sádico e cínico do poder:

Depois de chupar a bala, ele a enfiou na arma e girou o tambor, fechando-o com força. Hassan enfiou o cano em sua boca, e você se agachou com os braços suplicantes pra cima. Tira a cueca, ele disse, senão atiro. Você sentiu o gosto frio do metal na língua, parecido com o do fenobarbital. Negou pela terceira vez. Hassan apertou o gatilho três vezes. Teeec. Teeec. Teeec. Ele puxou o cano pra fora de sua boca, e a alça da mira rasgou seu lábio superior. O quarto tiro foi pra cima, e o barulho afugentou tuiuiús à espreita em cima das árvores. O primeiro murro atingiu-o na boca, o segundo no olho direito, o terceiro no nariz. Você sentiu o cheiro de pólvora no ar. As porradas seguintes se concentraram em seus dentes, que amoleceram após alguns minutos (Terron, 2017a, p. 167).

Hassan Sader Gamarra encarna o narcisismo do sujeito totalitário (Olivieri-Godet, 2009), o sentimento de onipotência e, ao mesmo tempo, de impunidade próprios ao torturador por se saber protegido pelo sistema tirânico vigente, que lhe possibilita, inclusive, o exercício privado do terror. O romance realiza um cruzamento estilístico entre o realismo feroz das cenas de tortura, compartilhado por várias narrativas da ditadura militar, e a descrição expressionista da paisagem como fazendo parte integrante de um ambiente assustador, no qual evoluem tuiuiús devorando cadáveres (Terron, 2017a, p. 128), sucuris engolindo seres humanos (Terron, 2017a, p. 212), cães famintos atacando defunto (Terron, 2017a, p. 295), urubus esvaziando carcaças (Terron, 2017a, p. 434). Essas e outras imagens disseminadas no tecido ficcional, como a flor-vampiro vinculada às catástrofes evocadas no romance, conotam a permanência da barbárie, compondo o universo distópico da narrativa: "Não é preciso se esforçar para prever as desgraças que nos aguardam: doença, pobreza, mutilação, cegueira e morte" (Terron, 2017a, p. 430).

A representação do despotismo e da tirania do poder explora a encenação de atos de tortura e de perseguição, tecendo relações entre suas diversas manifestações, no tempo e no espaço, responsáveis pela instauração do clima de ódio e terror. Essas associações são sugeridas na caracterização do grupo de adolescentes torturadores cognominado os "Botinas Negras", liderados por Hassan Sader Gamarra. A alusão ao uniforme dos nazistas é claramente identificada, mesclada ao verde-oliva das fardas dos militares brasileiros, enquanto o jogo de 
palavras embutido no nome do líder do grupo induz a referência ao ditador Saddam Hussein, evocando a memória traumática da invasão do Iraque. Quanto a "Gamarra", o trocadilho lembra Gomorra, título de romance, filme e série televisiva italiana que retrata as ações brutais da máfia napolitana da Camorra. Observa-se a multiplicação de alusões às catástrofes coletivas do século XX e XXI, ratificando a afirmação de Marianne Hirsch, que considera que diante desse fenômeno de multiplicação das catástrofes, incluindo aí as ditaduras latino-americanas, a Shoa não constitui mais a referência absoluta (Hirsch, 2013).

O processo de escrita nutre-se de uma intensa prática intertextual e intersemiótica. Absorve e transforma referências diversas, das clássicas às vanguardistas e populares, além de explorar o diálogo com outras linguagens artísticas e midiáticas: fiç̧ão científica, filmes de terror, séries televisivas e videogames, cujo núcleo narrativo estrutura-se em torno da perseguição da "caça" (objeto ou ser que se deseja possuir/destruir) pelo "caçador" (justiceiro/assassino/exterminador). A dimensão irônica do romance apropria-se de um imaginário envenenado pelas imagens icônicas da violência televisiva e da mídia visual. Adere a uma prática intersemiótica parodiando as imagens clichês da violência, que, na contemporaneidade, segundo Beatriz Resende, viraram "fonte de divertissement" (Resende, 2008, p. 38). A narrativa mistura fatos reais com outros inventados, personagens históricos e outros irreais, explorando as fronteiras entre o referencial e o fictício.

No mundo recriado pelo romance, marcado por uma extrema negatividade, os personagens ou são presas, ou são carrascos. Em contextos onde impera a violência totalitária, não há lugar para identidades fragilizadas e angustiadas, como a do menino desmemoriado, nem para utopias como a que alimenta o guerrilheiro Karl Reiners, personagens errantes e derrotados, cuja passagem pela vida, ameaçados pelos abutres sempre à espreita, assemelha-se a uma estação no inferno.

Desse modo, a perspectiva sustentada pelo romance é a de que a barbárie é constitutiva do mundo humano, ela tece o fio da continuidade histórica. Se o presente da narrativa corresponde ao período da ditadura militar, o movimento retrospectivo e prospectivo que a mesma instaura acentua uma representação imbricada das experiências traumáticas, seja pela permanência de elementos que compõem a figuração espacial ou pelos personagens diversos que encarnam a figura do algoz, componentes responsáveis pela sua atmosfera opressiva ou ainda, como assinala Camila Von Holdefer, na sua resenha, "pela nebulosidade discursiva devido à superposição de vozes que falam através de outras vozes, em um processo que rompe as barreiras do tempo e do espaço" (Holdefer, 2017). A ousadia formal da ficção de Terron aposta numa construção narrativa labiríntica, de múltiplas vozes e versões, acentuando o caráter intangível e contraditório do real. A violência e o autoritarismo aparecem como traços legíveis e permanentes, como desdobramentos do passado no presente, revelando a adesão da narrativa a uma visão trágica do real.

Os fragmentos que constroem a história de vida e morte do guerrilheiro Karl Reiners ilustram bem essa tendência labiríntica da narrativa que também aflora na elaboração da saga familiar. A dimensão da memória genealógica remonta às raízes dos seus ascendentes, interligando o itinerário de vida do avô Georg Reiners, na colônia Nueva Germania de imigrantes alemães, à ditadura de Vargas e à Segunda Guerra. A construção ambígua da identidade enigmática do personagem do avô aparece desde a reconstituição de sua infância, em que ele é apresentado como um inocente garoto, habitante da colônia Nueva Germania, pobre e doente em estado terminal, portador do vírus da raiva (Terron, 2017a, p. 388) e salvo pelos dons obscuros de um velho índio kadiwéu. Adulto, por trás do semblante de um velho solitário e contemplativo, proprietário da fazenda "Sumidouro", insinua-se a personalidade do terrível exterminador e torturador El Cazador Blanco, figura emblemática, no romance, da herança da prática da tortura e dos crimes dos regimes totalitários: "a família Reiners tinha inaugurado seu lugar naquele pântano do Mato Grosso, como animais e pragas vegetais que coexistiam em silêncio" (Terron, 2017a, p. 461).

Superpõem-se a essas remissões lacunares ao passado, familiar e coletivo, as imagens da fuga de Karl através do Cerrado e do Pantanal, em dois momentos: na noite do Golpe de 1964, quando entra na clandestinidade, e dez anos mais tarde, em sua errância solitária e trágica, após o 
massacre da Guerrilha do Araguaia. À utopia do engajamento inicial, marcada pelo idealismo dos militantes de esquerda que Karl Reiners representa, alvo da ironia crítica da narrativa (Terron, 2017a, p. 124), sucede o arrependimento pelo sequestro do menino alemão e a consciência do fim, caçado feito um animal pelos militares, no espaço abissal e opressivo da selva do Araguaia: "o corpo de Karl Reiners foi abandonado ao temporal intermitente pelos soldados, atraindo cães famintos" (Terron, 2017a, p. 295). A referência à Guerrilha do Araguaia, acontecimento emblemático da violência extrema da Ditadura Militar, cujo "caráter fantasmático", ressaltado por Vecchi (2014) e lembrado por Eurídice Figueiredo (2017, p. 90), "representa o ausente-presente, o morto que volta porque não teve seu sepultamento sacralizado pelos ritos fúnebres" (Figueiredo, 2017, p. 97), faz emergir a memória do esquecimento, o passado traumático que se quer apagar. Para além da articulação histórica que permite sinalizar o passado da contemporaneidade ${ }^{5}$ a narrativa induz uma reflexão ontológica sobre a condição humana, ao encenar situações extremas que desvelam a face abominável de sua natureza.

\section{Entre mise en scène distópica e luminosidade da linguagem}

A ficção distópica e plural de Joca Reiners Terron erige um universo inédito e inesgotável, chamando a atenção do leitor para a própria fatura do texto como elemento articulador de sentido, para além do conteúdo do que está sendo narrado. A modalidade de inscrição dos acontecimentos históricos na narrativa opta pelo imbricamento dos mesmos, tomando como eixo a ditadura militar brasileira, movendo-se para o passado e prospectando o futuro, com o objetivo de interrogar as origens dos acontecimentos trágicos (guerras, ditaduras, holocausto, endemias) e de expor a monstruosidade dos aparelhos estatais e sua permanência no tempo. A inscrição dos elementos espaciais obedece a um movimento similar, devido ao fato de o romance recusar uma estrutura espaço-temporal fixa. A representação expressionista do Pantanal dota-o de características opressivas, aproximando-o dos espaços das prisões e dos campos de concentração, como a prisão de Ilha Grande e o centro de extermínio de Bernburg, lugares onde os destinos de personagens reais e fictícios se cruzam.

O caráter distópico do romance aparece igualmente na narração do mito da origem da pyhareryepypepyhare, a flor-vampiro, a flor do mal baudelairiana, um dos múltiplos significados que o texto lhe atribui, explorando, a partir de figuras híbridas e grotescas, o campo do inumano. Procura assim compor um mundo insano, incoerente e inquietante, abrindo-se a questionamentos de ordem metafísica, marcado por uma visão negativa da existência. Entre os diversos vínculos dialógicos textualizados pelo discurso romanesco para expressar a herança maldita do humano, abraçando uma perspectiva niilista, destaca-se, nas páginas finais, a homenagem a Machado de Assis. As palavras gravadas pela rata, endereçadas ao menino desmemoriado, fazem eco às do defunto-autor Brás Cubas, que se nega a transmitir ao mundo "o legado da nossa miséria" (Assis, 1985, p. 639):

Esta história é sobre nós, mas você vai contá-la como se fosse sobre outros.

Mas hoje o que eu tenho a dizer pra você é algo diferente, é um pedido. Nunca tenha filhos. Encerre essa família insepulta, chegou a hora de nossa extinção. Já basta de seres humanos neste planeta, não acha (Terron, 2017a, p. 460-461).

A dimensão fundamentalmente trágica da distopia anuncia o final apocalíptico do romance. Ela fecha as portas para possíveis alternativas e penetra no "empire familier des ténèbres futures" (fazendo menção ao trecho de Les fleurs du mal em epígrafe): "Ninguém estava a salvo. Era o fim do mundo, o fim do seu mundo" (Terron, 2017a, p. 463).

Resta a revelação efêmera e iluminada da obra, fragmentos de uma memória do esquecimento que o romance se dedica a fazer emergir, ao mesmo tempo em que problematiza

\footnotetext{
${ }^{5}$ Refiro-me ao anacronismo da contemporaneidade (Agamben, 2008, p. 9-11) ou, nas palavras de Robert Dion, "o caráter de não contemporaneidade da contemporaneidade", o "passé du présent" que o autor relaciona com as questões de filiação e herança, ou seja com "a mise en scène literária da história, grande e pequena, universal e pessoal, e sobre suas consequências sobre a escrita no presente" (Dion e Mercier, 2019, p. 27, tradução nossa). Ver também Dion (2019a; 2019b).
} 
as relações entre linguagem e realidade, como é possível observar na referência às estátuas de gelo da rata, esculturas que figuram o congelamento do fluxo do tempo e funcionam como uma mise en abyme do processo de composição e da temática do romance: "uma estátua de gelo cuja composição pode ser vista por alguns segundos, o tempo do calor derreter suas formas, e sua significação ficar perdida para sempre, como o corpo de Karl também está" (Terron, 2017a, p. 303). As esculturas da rata espelham a precariedade do sentido que se manifesta no enredo descontínuo do romance, explorando as tensões entre o real e a sensação de irrealidade. A imaginação supre as lacunas da memória sobre os desaparecidos da ditadura, os corpos torturados, os massacres das aldeias indígenas. As imagens cruas e fantasmagóricas de Noite dentro da noite interpelam os cenários sangrentos da história e a permanência do seu legado destruidor na contemporaneidade, levando o leitor a constatar, por fim, que "Esta história é sobre nós" (Terron, 2017a, p. 460).

No tratamento das questões de filiação e herança, o romance imbrica as dimensões individual e coletiva da herança maldita. No seu estudo sobre a construção do contemporâneo, Robert Dion considera que, ao inquirir sobre o "passado do presente", as narrativas contemporâneas realizam uma mise en scène literária da história, grande e pequena, universal e pessoal, debruçando-se sobre suas consequências na escrita no presente (Dion, 2019a, p. 317356). Em Noite dentro da noite, o ato de escrever sobre acontecimentos traumáticos é lacunar e angustiante, sugerindo a permanência da ancestralidade maldita no presente. Situando-se no limbo entre esquecimento, rememoração e invenção, tal qual o menino desmemoriado, o autor recorre à imaginação para preencher "os espaços deixados pelo esquecimento" (Terron, 2017a, p. 451). Por um lapso de tempo - o da escrita, o da leitura - a potência transformadora e reveladora da linguagem emancipa-nos da recorrência traumática.

\section{Referências}

AGAMBEN, Giorgio (2008). Qu'est-ce que le contemporain? Paris: Payot.

ASSIS, Machado de (1985). Memórias Póstumas de Brás Cubas. In: ASSIS, Machado de. Obra completa Rio de Janeiro: Editora Nova Aguilar. v. 1, p. 510-639.

BERND, Zilá (2018). A persistência da memória. Romances da anterioridade e seus modos de transmissão intergeracional. Porto Alegre: BesouroBox.

BRANDÃO, Ignácio de Loyola (1971/1982). Zero. Rio de Janeiro: Codecri.

CALLADO, Antonio (1977). Reflexos do baile. Rio de Janeiro: Paz e Terra.

DALCASTAGNÈ, Regina (1996). O espaço da dor: o regime de 64 no romance brasileiro. Brasília: Editora da UnB.

DION, Robert (2019a). Le passé du présent. DION, Robert; MERCIER, André. La construction du contemporain. Montréal: Les Presses de l'Université de Montréal. p. 317-356

DION, Robert (2019b). Venir après: filiation et héritage. DION, Robert; MERCIER, André. La construction du contemporain. Montréal: Les Presses de l'Université de Montréal. p. 133-157.

DION, Robert; MERCIER, André (2019). La construction du contemporain. Montréal: Presses de l'Université du Montréal.

FIGUEIREDO, Eurídice (2017). A literatura como arquivo da ditadura brasileira. Rio de Janeiro: 7Letras.

GABEIRA, Fernando (1979). O que é isso companheiro. Rio de Janeiro: Codecri.

HIRSCH, Marianne (2013). Postmémoire/Postmemory. Entretien. Art Absolument, Paris, p. 6-11. Disponível em: https:// bit.ly/3doBZgV. Acesso em: 25 jun. 2019.

HOBSBAWM, Eric (2003). L'âge des extrêmes. Histoire du court XXe siècle. Paris: Editions Complexe.

HOLDEFER, Camila Von (2017). Noite dentro da noite: uma estrada muito comprida que apesar de reta tinha curvas. Blog Camila Von Holdefer, 20 jun. Disponível em: https:/ / bit.ly/2UdgoR0. Acesso em 23 jun. 2019. 
HOSSNE, Andrea Saad (2016). Intimité et corrosion. Narrateur et récits d'une mémoire (historique) introjectée. In: OLIVIERI-GODET, Rita (Ed.). Cartographies littéraires du Brésil actuel: espaces, acteurs et mouvements sociaux. Bruxelles: P.I.E. Peter Lang, p. 43-57.

HUYSSEN, Andreas (2000). Seduzidos pela memória. Rio de Janeiro: Aeroplano.

IMBERT, Christophe; MAUPEU, Philippe (2012). Le paysage allégorique: entre image mentale et pays transfiguré. Rennes: PUR.

OLIVIERI-GODET, Rita (2009). Sujeito totalitário e violência em Viva o povo brasileiro e Diário do farol. In: OLIVIERI-GODET, Rita. Construções identitárias na obra de João Ubaldo Ribeiro. São Paulo: Hucitec; Feira de Santana, BA: UEFS Ed.; Rio de Janeiro: Academia Brasileira de Letras. p. 187-210.

PELLEGRINI, Tânia (2018). Resistir, documentando: realismo e ditadura militar. In: PELLEGRINI, Tânia. Realismo e realidade na literatura. São Paulo: Alameda. p. 183-218.

RESENDE, Beatriz (2008). Contemporâneos: expressões da literatura brasileira no século XXI. Rio de Janeiro: Casa da Palavra.

SARLO, Beatriz (2007). Tempo passado. Cultura da memória e guinada subjetiva. São Paulo, Belo Horizonte: Companhia das Letras; UFMG.

SIRKIS, Alfredo (1980/2014). Os carbonários: memórias da guerrilha perdida. Rio de Janeiro: Bestbolso.

TAPAJÓS, Renato (1977). Em câmara lenta. São Paulo: Alfa-Ômega.

TERRON, Joca Reiners (2003). Curva de rio sujo. São Paulo: Planeta.

TERRON, Joca Reiners (2017a). Noite dentro da noite. São Paulo: Companhia das Letras.

TERRON, Joca Reiners (2017b). Romance autobiográfico de Joca Reiners Terron explora como foi crescer durante a ditadura militar. [Entrevista concedida a] Guilherme Sabota. O Estado de S. Paulo, 25 mar. Disponível em: https:/ / bit.ly/2U7JNfI. Acesso em: 8 jun. 2019.

TERRON, Joca Reiners (2017c). Joca Reiners Terron lança em BH romance Noite dentro da noite. [Entrevista concedida a] Pedro Antunes. Uai, Belo Horizonte, 9 abr. Disponível em: https://bit.ly/2RWxyQr. Acesso em: 7 jun. 2019.

VECCHI, Roberto (2014). O passado subtraído da desaparição forçada: Araguaia como palimpsesto. Estudos de Literatura Brasileira Contemporânea, Brasília, n. 43, p. 133-139, jan./jun. Disponível em: https:/ / www.redalyc.org/articulo.oa?id=323130679008. Acesso em: 30 out. 2018.

VERÍSSIMO, Érico (1971/1977). Incidente em Antares. Porto Alegre: Editora Globo. 